\title{
PENERAPAN MODEL PEMBELAJARAN KOOPERATIF STAD UNTUK MENINGKATKAN HASIL BELAJAR PENJUMLAHAN DAN PENGURANGAN BILANGAN PECAHAN
}

\author{
Akhmad Bisri Arifin \\ Kepala SDN Kaligoro Kec. Kutorejo, Kabupaten Mojokerto \\ Email: 12.02.61@gmail.com
}

\begin{tabular}{l}
\hline Tersedia Online di \\
\hline http://www.jurnal.unublitar.ac.id/ \\
index.php/briliant \\
\hline \\
\hline Sejarah Artikel \\
\hline Diterima pada 2 Januari 2017 \\
Disetuji pada 20 Januari 2017 \\
Dipublikasikan pada 1 Februari \\
2017 Hal. 12 -17
\end{tabular}

\begin{tabular}{l}
\hline Kata Kunci: \\
\hline stad, hasil belajar, penjumlahan \\
dan pengurangan, pecahan
\end{tabular}

\begin{abstract}
Abstrak: Tujuan penelitian ini adalah untuk meningkatkan aktivitas belajar siswa dan hasil belajar siswa dengan model pembelajaran kooperatif tipe STAD. Penelitian ini adalah Penelitian Tindakan Kelas (PTK). Penelitian dilakukan selama 2 siklus dengan subyek siswa kelas V sebanyak 29 siswa di SDN Kaligoro Kecamatan Kutorejo Tahun 2016/2017. Berdasarkan hasil penelitian selama dua siklus diperoleh prosentase aktivitas peserta didik dalam model pembelajaran kooperatif tipe STAD meningkat menjadi $86,7 \%$ pada siklus II dan dikategorikan sangat aktif. Hasil belajar peserta didik dalam pembelajaran kooperatif tipe STAD perolehan nilai rata-rata peserta didik pada siklus II nilai rata-rata peserta didik meningkat menjadi 80,17 dengan prosentase ketuntasan 93,10\%.
\end{abstract}

Kemajuan kehidupan masyarakat dalam suatu negara sangat dipengaruhi oleh beberapa faktor, faktor utama yang tidak bisa lepas yaitu dunia pendidikan. Untuk menciptakan suatu negara yang mempunyai masyarakat yang maju, maka suatu negara dituntut untuk aktif dan secara berkesinambungan menciptakan terobosan-terobosan dalam upaya memajukan dunia pendidikan di setiap jenjang. Pendidikan pada hakikatnya akan mencakup kegiatan mendidik, mengajar, dan melatih. Sehingga dalam pelaksanaannya ketiga kegiatan tadi harus berjalan secara serempak, terpadu, dan berkelanjutan, serta serasi dengan perkembangan anak didik serta lingkungan hidupnya. (Lamijan, dkk,2007:9). Pendidikan adalah usaha sadar dan terencana untuk mewujudkan suasana belajar dan proses pembelajaran agar peserta didik secara aktif mengembangkan potensi dirinya untuk memiliki kekuatan spiritual keagamaan, pengendalian diri, kepribadian, kecerdasan, akhlak mulia, serta keterampilan yang dibutuhkan bagi dirinya, masyarakat, bangsa dan negara (UU No. 20 tahun 2003).

Pendidikan adalah segala situasi hidup yang mempengaruhi pertumbuhan individu sebagai pengalaman belajar yang berlangsung dalam segala lingkungan dan sepanjang hidup (Sagala, S., 2011:1). Pertumbuhan individu khususnya siswa yang berlangsung sepanjang hidupnya tentunya tidak terlepas dari suatu masalah. Masalah harus diselesaikan dan dalam menyelesaikan masalah tentunya dibutuhkan pemikiran yang logis dan sistematis. Salah satu mata pelajaran yang melatih siswa untuk berfikir logis dan sistematis adalah matematika. Matematika 
merupakan salah satu alat untuk mengembangkan cara berfikir seseorang. Hal ini merupakan salah satu alasan matematika perlu untuk diberikan kepada peserta didik sejak jenjang pendidikan dasar (Hudoyo, H., 2005:35). Penguasaan terhadap matematika akan membantu peserta didik memecahkan berbagai permasalahan dalam kehidupan sehari-hari termasuk yang terkait dengan kemajuan IPTEK. Banyak permasalahan dalam kehidupan sehari-hari dapat dimodelkan dengan matematika misalnya saja permasalahan-permasalahan pada masalah optimalisasi (maksimum dan minimum) yaitu pada suatu masalah dengan keterbatasan sumber daya dengan tujuan untuk memperoleh keuntungan yang maksimum atau biaya yang minimum

Peneliti yang juga sebagai guru matematika SDN Kaligoro seringkali mendapat keluhan dari siswa masalah kesulitan yang dialaminya dalam menyelesaikan permasalahan yang ada pada penjumlahan dan pengurangan pada bilangan pecahan. Kesulitan siswa dalam menyelesaikan penjumlahan dan pengurangan bilangan pecahan ini ternyata juga peneliti alami pada saat peneliti mengajar pada semester gasal di kelas V pada tahun pelajaran 2016/2017. Melihat kenyataan ini peneliti mengambil langkah mencari teman sejawat yang sama-sama guru matematika untuk mendiskusikan mengenai metode pembelajaran apa cocok diterapkan, bagaimana membuat suasana belajar lebih menyenangkan, bagaimana hasil belajar siswa supaya bisa meningkat, mengapa masih banyak siswa yang memperoleh nilai dibawah KKM yang telah ditetapkan yaitu sebesar 70 .

Berdasarkan hal tersebut peneliti menawarkan suatu tindakan sebagai alternatif untuk mengatasi masalah yang ada berupa peneraapan model pembelajaran kooperatif. tipe STAD. Hal ini dikarenakan pembelajaran kooperatif tipe STAD (StudentTeams Achievement Division) merupakan salah satu tipe pembelajaran kooperatif yang menekankan pada aktivitas dan interaksi diantara siswa untuk saling memotivasi dan saling membantu dalam menguasai materi pelajaran guna mencapai prestasi yang maksimal (Lindayani, 2011 : 93). Adapun rumusan masalah dalam penelitian ini adalah (1). Bagaimana peningkatan aktivitas belajar siswa dengan menggunakan model pembelajaran kooperatif tipe STAD. (2). Bagaimana respon siswa terhadap penerapan pembelajaran kooperatif tipe STAD. (3). Bagaimana peningkatan hasil belajar siswa dengan menggunakan model pembelajaran kooperatif tipe STAD.

\section{METODE}

Jenis penelitian ini adalah penelitian tindakan kelas (PTK). Sesuai dengan jenisnya penelitian ini terdapat empat tahapan yang dilakukan, diantaranya planning (rencana), acting (tindakan), observing (pengamatan), dan reflecting (refleksi). Perencanaan dalam penelitian ini dibuat pada tahap awal berupa rumusan dan tujuan masalah, serta pembuatan perangkat pembelajaran (RPP), instrumen penelitian yaitu lembar observasi aktivitas siswa. Adapun materi dalam RPP yang akan disampaikan adalah sebagai berikut : pertemuan 1 materi yang disampaikan mengenai penjumlahan pada bilangan pecahan. Pada pertemuan 2 melenjutkan operasi penjumlahan dan melakukan tes hasil belajara Selain itu peneliti juga menyusun instrumen penelitian yang berupa lembar observasi aktivitas siswa dan soal tes belajar siswa.

13 BRILLIANT: Jurnal Riset dan Konseptual Volume 2 Nomor 1, Februari 2017 
Instrumen penelitian dalam pengamatan ini digunakan untuk memperolah atau mengumpulkan data dalam rangka memcahkan masalah penelitian atau untuk mencapai tujuan penelitian. Dalam penelitian ini instrumen yang digunakan ada 3 yaitu: (a) Lembar observasi aktivitas siswa dianalisis menggunakan rumus keaktifan siswa $=$ jumlah skor dibagi skor maksimal dikali 100. Dengan aktivitas siswa secara klasikal untuk masing-masing indikator lebih dari $75 \%$. (b) tes hasil belajar dengan ketuntasan hasil belajar secara individu > 70, 2) Ketuntasan hasil belajar secara klasikal > $80 \%$ ). (c) Angket respon siswa terhadap pembelajaran. Pembelajaran dikatakan berhasil jika mencapai presentase antara $60 \%$ sampai $100 \%$.

\section{HASIL DAN PEMBAHASAN}

\section{Siklus I}

Pelaksanaan tindakan siklus I terdiri dari dua pertemuan, alokasi waktu setiap pertemuan adalah 2 x 45 menit. Pertemuan pertama siklus I dilakukan pembelajaran pada hari selasa tanggal 5 September 2016 dengan sub materi penjumlahan pada bilangan pecahan dengan menggunakan model pembelajaran kooperatif tipe STAD (Student Teams Achievement Division). Siklus I terdiri dari beberapa tahap yaitu tahap perencanaan, pelaksanaan, observasi, dan refleksi.

\section{Tahap perencanaan}

Peneliti membuat rencana kegiatan pembelajaran, mempersiapkan lembar kerja, dan membuat instrumen penelitian. Rencana kegiatan pembelajaran dibuat berdasarkan langkah pembelajaran sesuai dengan kurikulum yang dipakai yang dikombinasikan dengan model pembelajaran kooperatif tipe STAD (Student Teams Achievement Division).

\section{Tahap pelaksanaan}

Tahap 1 pelaksanaan dilaksanakan hari Senin tanggal 5 September 2016 dengan alokasi waktu 2 x 45 menit dengan menerapkan pembelajaran kooperatif tipe STAD (Student Teams Achievement Division) dengan sub pokok bahasan penjumlahan bilangan pecahan.

Pada saat proses belajar berlangsung, observer juga mengamati segala aktivitas belajar siswa dengan menggunakan lembar observasi aktivitas belajar siswa. Dalam mengisi lembar observasi tersebut, observer juga memperhatikan indikator penilaian aktivitas belajar siswa sehingga dapat diperoleh hasil yang real.

Pertemuan kedua dilaksanakan pada hari kamis 8 September 2016. Wujud pelaksanaan pertemuan kedua adalah sebagai berikut. (1) Guru memberikan evaluasi hasil belajar tentang materi pembelajaran yang telah dilaksanakan dengan memberikan tugas secara individual berupa tes/kuis. (2) Guru menginformasikan kepada siswa untuk mempelajari materi selanjutnya. (3) Guru menutup kegiatan belajar mengajar dengan doa dan salam.

\section{Tahap Pengamatan}

14 BRILLIANT: Jurnal Riset dan Konseptual Volume 2 Nomor 1, Februari 2017 
Kegiatan observasi dilakukan oleh teman sejawat yaitu guru mata pelajaran matematika yaitu mengamati kegiatan pembelajaran yang meliputi aktivitas belajar siswa.

Aktivitas Siswa, kegiatan observasi (pengamatan) dilakukan oleh observer yaitu dengan menggunakan instrumen berupa lembar observasi yang mengukur kemampuan kualitas tentang pembelajaran yang sedang berlangsung dan sekaligus membuat membuat tabulasi untuk meringkas data. Berdasarkan hasil pengamatan didapat Aktivitas belajar klasikal siswa dalam model pembelajaran kooperatif tipe STAD (Student Teams Achievement Division) pada siklus I sebesar $60 \%$ dengan katagori Cukup Aktif.

Hasil belajar siswa pada siklus I dengan jumlah 29 siswa terdapat 20 siswa yang tuntas dan terdapat 9 siswa yang belum tuntas. Terlihat bahwa ketuntasan klasikal tercapai sebesar 68,97 \%. Hasil belajar pada siklus I nilai rataratanya adalah 74,48 .

\section{Tahap Refleksi}

Refleksi dimaksudkan untuk mengkaji secara menyeluruh tindakan yang telah dilakukan pada siklus I apakah sudah mencapai indikator keberhasilan tindakan atau belum. Jika belum maka akan dicari kekurangan-kekurangan yang ada yang selanjutnya akan diperbaiki pada siklus II.

Aktivitas siswa pada siklus I sebesar 60\% (Cukup Aktif) dapat dikatakan belum mencapai kriteria yang telah ditetapkan yaitu $75 \%$.sehingga perlu ditingkatkan dengan tindakan, Guru harus tegas lagi dalam membimbing atau memotivasi siswa untuk lebih baik lagi dalam berkelompok, tidak boleh ada yang ramai, semua harus memperhatikan penjelasan guru, siswa harus bersosialisasi dengan baik dengan kelompoknya, serta dalam mempresentasikan hasil pekerjaannya harus dibagi rata dalam pembagian tugasnya.

Hasil belajar yang dicapai yaitu Ketuntasan secara klasikal sebesar 68,97 $\%$. dengan nilai rata-ratanya adalah 74,48 belum mencapai kriteria yang telah ditetapkan sebesar $80 \%$, maka perlu diadakan perbaikan yaitu : siswa harus lebih memperhatikan penjelasan guru, lebih teliti dalam mengerjakan dan membaca soal.

\section{Siklus II}

Siklus II dilaksanakan 2 pertemuan. Pertemuan 1 pada hari Senin 12 September 2016 dengan alokasi waktu 2 x 45 menit. Pertemuan 2 hari Kamis 15 September 2016. Sesuai dengan prosedur kerja dalam Penelitian Tindakan Kelas (PTK) yang dirancang dan setiap siklusnya terdiri dari 4 tahap yaitu perencanaan, pelaksanaan, pengamatan, dan refleksi.

\section{Tahap perencanaan}

Tahap perencanaan pada siklus II hampir sama dengan siklus I. yang membedakan adalah dari segi guru, materi, dan soal kuis siswa. Semua perencaan peneliti implementasikan dalam RPP siklus II. Dalam tahap ini juga menyiapkan lembar observasi keaktivan siswa dan lembar tes untuk siklu II. 


\section{Tahap pelaksanaan}

Tahap pelaksanaan dilaksanakan dengan alokasi waktu 2 x 45 menit dengan menerapkan pembelajaran kooperatif tipe STAD (Student Teams Achievement Division) dengan materi pengurungan pada bilangan pecahan. Wujud pelaksanaan pada siklus II juga sama dengan siklus I.

\section{Tahap Pengamatan}

Kegiatan observasi (pengamatan) dilakukan oleh observer selaku guru matematika SDN Kaligoro Kutorejo Kabupaten Mojokerto. Pada tahap pengamatan peneliti bertindak sebagai guru dan teman sejawat bertindak sebagai observer. Hasil aktivitas belajar siswa secara klasikal mengalami peningkatan sebesar 26,27 \% yaitu dari $60 \%$ dengan kategori Cukup Aktif pada siklus I meningkat menjadi 86,27 \% dengan kategori Sangat Aktif pada siklus II.

Hasil belajar siswa pada siklus II mengalami peningkatan yaitu dari 29 jumlah siswa yang mengikuti kegiatan pembelajaran, terdapat 27 siswa tuntas mencapai nilai KKM. Presentase ketuntasan secara klasikal sebesar 93,10 \% dan nilai rata-rata sebesar 80,17 .

\section{Tahap Refleksi}

Refleksi secara menyeluruh tindakan yang telah dilakukan pada siklus II apakah sudah mencapai indikator keberhasilan tindakan atau belum. Jika belum maka akan dicari kekurangan-kekurangan yang ada yang selanjutnya akan diperbaiki pada siklus III.

Aktivitas siswa pada siklus II sebesar 86,7\% (Sangat Aktif) dapat dikatakan sudah mencapai kriteria yang telah ditetapkan yaitu $75 \%$. sehingga tidak perlu ditingkatkan dengan tindakan pada siklus berikutnya. Ketuntasan secara klasikal sebesar 93,10 \% . dengan nilai rata-ratanya adalah 80,17 sudah mencapai kriteria ketuntasan secara klasikal yang telah ditetapkan sebesar $80 \%$, sehingga tidak perlu diadakan perbaikan pada siklus berikutnya.

Angket respon siswa dibagikan diakhir pertemuan pada siklus II, setelah selesai diadakan pembelajaran kooperatif tipe STAD (Student Teams Achievement Division). Berikut hasil angket respon siswa kelas V SDN Kaligoro I, diperoleh data rata-rata frekuensi siswa yang menjawab "Ya" sebesar 27,85 yang mendukung pembelajaran, rata-rata frekuensi siswa yang menjawab "Tidak" yang kurang mendukung pembelajaran STAD sebesar 1,13. Apabila diprosentase ratarata siswa yang menjawab "Ya" sebesar 96,03\% dan presentase rata-rata siswa yang menjawab "Tidak" sebesar 5,87\%.

\section{KESIMPULAN}

Berdasarkan hasil penelitian yang diperoleh setelah pemberian tindakan dengan model pembelajaran kooperatif tipe STAD (Student Teams Achiement Division) pada materi pokok penjumlahan dan pengurangan pada bilangan pecahan, ada beberapa hal yang dapat disimpulkan, diantaranya: (1) Pembelajaran berkelompok menggunakan model pembelajaran kooperatif tipe STAD (Student Teams Achievement Division) dapat meningkatkan aktivitas. Terlihat dari prosentase aktivitas belajar siswa sebesar $60,5 \%$ pada siklus I dengan kategori

16 BRILLIANT: Jurnal Riset dan Konseptual Volume 2 Nomor 1, Februari 2017 
cukup aktif meningkat menjadi $84 \%$ pada siklus II dengan kategori sangat aktif. (2) Hasil angket respon siswa sudah melebihi $80 \%$, jadi dapat disimpulkan respon siswa kelas V SDN Kaligoro Kutorejo Kabupaten Mojokerto sangat baik dalam pembelajaran kooperatiif tipe STAD (Student Teams Achiement Division). (3) Penerapan model pembelajaran kooperatif tipe STAD (Student Teams Achiement Division) dapat meningkatkan hasil belajar siswa kelas V SDN Kaligoro pada materi penjumlahan dan pengurangan pada bilangan bulat tahun ajaran 2016/2017.

\section{SARAN}

Penelitian yang telah dilakukan dengan model pembelajaran kooperatiif tipe STAD (Student Teams Achiement Division) untuk meningkatkan hasil belajar dan aktivitas siswa pada materi penjumlahan dan pengurangan pada bilangan bulat, dapat disampaikan beberapa saran sebagai berikut: (1) Dalam kegiatan belajar mengajar, guru diharapkan menjadikan model pembelajaran kooperatif tipe STAD (Student Teams Achiement Division) sebagai salah satu alternatif dalam menyampaikan mata pelajaran matematika untuk meningkatkan aktivitas belajar dan hasil belajar siswa. (2) Pelaksanaan model pembelajaran kooperatiif tipe STAD (Student Teams Achiement Division), hendaknya guru mengkoordinir siswa dalam berdiskusi dengan baik mampu memberikan penjelasan materi dengan baik agar seluruh peserta didik mmapu memahami materi sehingga tujuan dari model pembelajaran kooperatiif tipe STAD (Student Teams Achiement Division) ini dapat tercapai.

\section{DAFTAR RUJUKAN}

Arikunto, Suharsimi. 2010. Prosedur Penelitian: Suatu Pendekatan Praktik. Jakarta: Rineka Cipta

Hudoyo, Herman. 2005. Pengembangan Kurikulum dan Pembelajaran Matematika. Malang: Universitas Negeri Malang.

Lindayani, D.A. dan M. Ali Murtadlo. 2011. Manajemen Pembelajaran Inovatif. Surabaya: Iranti Mitra Utama

Riduwan dan Akdon. 2010. Rumus dan Data dalam Analisis Statistika. Bandung: Alfabeta

Sagala, Syaiful. 2011. Belajar dan Pembelajaran. Bandung : Alfabeta

Undang-Undang No. 20 Tahun 2003. 2003. Sistem Pendidikan Nasional 2003. Jakarta: Cemerlang. 